\title{
Correction to: Sodium-glucose cotransporter 2 inhibitors (SGLT2i) and cardiac arrhythmias: a systematic review and meta-analysis
}

Hang-Long Li ${ }^{1,6}{ }^{0}$, Gregory Y. H. Lip ${ }^{2,3}$, Qi Feng ${ }^{4}$, Yue Fei ${ }^{5}$, Yi-Kei Tse ${ }^{1}$, Mei-zhen Wu ${ }^{1,6}$, Qing-wen Ren ${ }^{1,6}$, Hung-Fat Tse ${ }^{1,6}$, Bernard-M. Y. Cheung ${ }^{5}$ and Kai-Hang Yiu ${ }^{1,6^{*}}$ (i)

\section{Correction to: Cardiovasc Diabetol (2021) 20:100}

https://doi.org/10.1186/s12933-021-01293-8

Following publication of the original article [1], the authors noticed an error in the second author's name.

The name of the second author, "Gregory Y. H. Lip", was incorrectly written as "Gregory-Y H Lip". This has been corrected with this erratum.

The original article [1] has been corrected.

\section{Reference}

1. Li HL, Lip GYH, Feng Q, Fei Y, Tse YK, Wu M, Ren Q, Tse HF, Cheung BMY, Yiu KH. Sodium-glucose cotransporter 2 inhibitors (SGLT2i) and cardiac arrhythmias: a systematic review and meta-analysis. Cardiovasc Diabetol. 2021;20:100. https://doi.org/10.1186/s12933-021-01293-8.

\section{Publisher's Note}

Springer Nature remains neutral with regard to jurisdictional claims in published maps and institutional affiliations.

\begin{abstract}
Author details
'Division of Cardiology, Department of Medicine, The University of Hong Kong, Queen Mary Hospital, Room 1929B/K1931, Block K, Hong Kong, China. ${ }^{2}$ Liverpool Centre for Cardiovascular Science, University of Liverpool and Liverpool Heart \& Chest Hospital, Liverpool, UK. ${ }^{3}$ Aalborg Thrombosis Research Unit, Department of Clinical Medicine, Aalborg University, Aalborg, Denmark. ${ }^{4}$ Jockey Club School of Public Health and Primary Care, The Chinese University of Hong Kong, Hong Kong, China. ${ }^{5}$ Division of Clinical Pharmacology, Department of Medicine, The University of Hong Kong, Queen Mary Hospital, Hong Kong, China. ${ }^{6}$ Division of Cardiology, Department of Medicine, The University of Hong Kong Shenzhen Hospital, Shenzhen, China.
\end{abstract}

Published online: 04 September 2021

The original article can be found online at https://doi.org/10.1186/s12933021-01293-8.

\footnotetext{
*Correspondence: khkyiu@hku.hk

1 Division of Cardiology, Department of Medicine, The University of Hong

Kong, Queen Mary Hospital, Room 1929B/K1931, Block K, Hong Kong,

China

Full list of author information is available at the end of the article
}

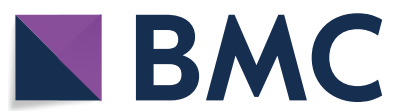

(C) The Author(s) 2021. Open Access This article is licensed under a Creative Commons Attribution 4.0 International License, which permits use, sharing, adaptation, distribution and reproduction in any medium or format, as long as you give appropriate credit to the original author(s) and the source, provide a link to the Creative Commons licence, and indicate if changes were made. The images or other third party material in this article are included in the article's Creative Commons licence, unless indicated otherwise in a credit line to the material. If material is not included in the article's Creative Commons licence and your intended use is not permitted by statutory regulation or exceeds the permitted use, you will need to obtain permission directly from the copyright holder. To view a copy of this licence, visit http://creativecommons.org/licenses/by/4.0/. The Creative Commons Public Domain Dedication waiver (http://creativeco mmons.org/publicdomain/zero/1.0/) applies to the data made available in this article, unless otherwise stated in a credit line to the data. 